\title{
SISTEM INFORMASI PENILAIAN (SIP) BDG JUARA: SEBUAH INOVASI UNTUK MENINGKATKAN PELAYANAN PUBLIK
}

\author{
Susy Ella ${ }^{1}$, Indra Risni Utami ${ }^{2}$ \\ ${ }^{1,2}$ Pusat Kajian dan Pendidikan dan Pelatihan Aparatur I, Lembaga Administrasi Negara \\ Bumi Perkemahan Jatinangor, Jl. Kiara Payung Km. 4,7 Sindangsari, Sukasari \\ Kabupaten Sumedang, Jawa Barat, 45366, Indonesia \\ No. Telp./HP: ${ }^{1}(022) 7790048,7782041 / 08121409606,{ }^{2} 08157142992$ \\ E-mail: ${ }^{1}$ susyella.lan@gmail.com, ${ }^{2}$ indra_lanbdg@yahoo.com
}

Naskah diterima tanggal 21 Juni 2017 direvisi tanggal 27 November 2017 disetujui tanggal 30 November 2017

\section{ASSESSMENT INFORMATION SYSTEM (AIS) BDG JUARA: AN INNOVATION TO IMPROVE PUBLIC SERVICE}

\begin{abstract}
The paradigm changes in public service require central and local governments to innovate. Moreover, public service policy also requires the government to deliver quality public services. Bandung city government is one of the local governments that has many public service innovations. One of the innovations which developed by Bandung City Government is SIP Bdg Juara. The innovation is an information system that built to assess the performance of subdistrict and urban village. The performance of camat (head of the subdistrict) and lurah (head of the urban village) is measured based on their activity reports that uploaded through SIP Bdg Juara application. Furthermore, the citizens are allowed to assess the performance of public services in their district. The purposes of this study were to analyze the implementation of SIP Bdg Juara and identify the advantages, disadvantages, and key factors of the innovation. This study used the qualitative method with case study approach. Data were collected through desk research, observation, and field research (interview). The results showed that SIP Bdg Juara can simplify the reporting and monitoring processes. It also encourages subdistrict and urban village to improve the performance of public services.
\end{abstract}

Keywords: assessment information system, SIP Bdg Juara, public service, subdistrict, urban village.

\begin{abstract}
Abstrak. Perubahan paradigma dalam pelayanan publik menuntut pemerintah baik pusat maupun daerah untuk berinovasi. Selain itu, kebijakan mengenai pelayanan publik juga mewajibkan pemerintah untuk memberikan pelayanan publik yang berkualitas. Pemerintah Kota Bandung merupakan salah satu pemerintah daerah yang memiliki banyak inovasi pelayanan publik. Salah satu inovasi yang dikembangkan oleh Pemerintah Kota Bandung adalah SIP Bdg Juara. Inovasi ini adalah sebuah sistem informasi yang dibangun untuk menilai kinerja kecamatan dan kelurahan. Kinerja camat dan lurah diukur berdasarkan laporan kegiatan yang diunggah melalui aplikasi SIP Bdg Juara. Selain itu, masyarakat juga bisa memberi penilaian terhadap kinerja pelayanan publik di wilayahnya. Tujuan penelitian ini adalah untuk menganalisis implementasi program SIP Bdg Juara dan mengidentifikasi kelebihan, kekurangan, dan faktor kuncinya. Metode penelitian yang digunakan adalah kualitatif dengan pendekatan studi kasus. Pengumpulan data melalui studi literatur, observasi, dan studi lapangan (wawancara). Hasil penelitian menunjukkan bahwa SIP Bdg Juara mempermudah proses pelaporan dan pengawasan. Serta mendorong kecamatan dan kelurahan untuk meningkatkan kinerja pelayanan publik.
\end{abstract}

Kata kunci: sistem informasi penilaian, SIP Bdg Juara, pelayanan publik, kecamatan, kelurahan.

DOI: $10.20422 / j p k . v 20 i 2.241$ 


\section{PENDAHULUAN}

Pelayanan publik telah dipandang berbeda sejak dimulainya era reformasi birokrasi. Baik bagi pemerintah maupun masyarakat, pelayanan publik tidak lagi sekedar pelayanan seadanya saja kepada masyarakat, namun merupakan pelayanan berkualitas yang memiliki standar pelayanan. Peningkatan kualitas pelayanan memang gencar dilakukan pemerintah karena menurut studi dari OECD dalam Wiseman (2014) bahwa kepuasan dan akuntabilitas terhadap kualitas pelayanan publik menjadi penentu utama kepercayaan masyarakat terhadap pemerintah.

Oleh karena itu, pemerintah mengeluarkan kebijakan berupa UndangUndang No. 25 Tahun 2009 Tentang Pelayanan Publik yang pada Pasal 15 disebutkan bahwa penyelenggara pelayanan publik berkewajiban untuk memberikan pelayanan yang berkualitas dan melaksanakan layanan sesuai dengan standar pelayanan yang telah disusun. Selain itu, daya kritis masyarakat semakin terasah sejak era keterbukaan informasi.

Masyarakat sudah leluasa mengkritik pemerintah jika layanan yang mereka terima tidak sesuai dengan yang diharapkan. Sebagaimana yang disebutkan dalam Masnurdiansyah (2016) bahwa secara nasional laporan paling banyak yang dikeluhkan masyarakat adalah tentang buruknya pelayanan publik di pemerintah daerah.

Untuk menghadapi tantangan tersebut maka inovasi adalah kunci utamanya. Sebagaimana yang disampaikan oleh Dwiyanto dalam Utomo (2017) bahwa keberhasilan melakukan inovasi akan dapat memperbaiki kualitas dan daya saing sektor publik. Sebaliknya, kegagalan melakukan inovasi akan membuat pemerintah kehilangan kepercayaan publik dan menurunkan daya saing. Salah satu daerah yang sadar inovasi adalah Kota Bandung sejak kepemimpinan Ridwan Kamil yang bertranformasi menjadi kota yang kaya akan inovasi. Terkait dengan pelayanan publik, ujung tombak pemerintahan daerah dalam memberikan pelayanan kepada masyarakat adalah kewilayahan (kecamatan dan kelurahan). Hal inilah yang kemudian mendorong Pemerintah Kota Bandung untuk meluncurkan terobosanterobosan baru yang melibatkan kecamatan dan kelurahan.

Salah satu inovasi yang berkaitan dengan kewilayahan adalah Sistem Informasi Penilaian (SIP) Bdg Juara. Inovasi berbasis teknologi ini merupakan sebuah tools bagi Pemerintah Kota Bandung untuk menilai kinerja camat dan lurah.

Sehingga camat maupun lurah diharapkan dapat terpacu untuk bersaing secara positif dalam rangka untuk memberikan pelayanan dan kinerja terbaiknya (Bandung.Co, 2015). Selain itu, diharapkan dapat mendorong masyarakat untuk mau berpartisipasi dalam pembangunan Kota Bandung karena aplikasi ini merupakan wadah bagi masyarakat untuk menilai kinerja layanan di kecamatan dan kelurahan Kota Bandung. Sesuai dengan ciri kota yang maju adalah meningkatnya partisipasi warga dalam semua aspek termasuk di antaranya pembangunan kewilayahan (Pikiran Rakyat, 2017).

Melihat besarnya potensi manfaat yang dapat diperoleh oleh Pemerintah Kota Bandung jika inovasi tersebut berjalan dengan baik, maka penulis memandang perlu untuk menelaah lebih jauh mengenai SIP Bdg Juara. Adapun tujuan dari penelitian ini adalah untuk menganalisis bagaimana implementasi program SIP Bdg Juara. Penelitian ini juga akan mengidentifikasi kelebihan, kekurangan serta key factors dalam pengembangan dan pelaksanaannya.

Kemudian menyimpulkan apakah inovasi ini sudah mampu mencapai tujuan pengembangannya. Sehingga selanjutnya hasil penelitian ini diharapkan dapat menjadi masukan bagi Pemerintah Kota Bandung untuk pengembangan SIP Bdg Juara ke depan. Selain itu, juga dapat menjadi referensi bagi pemerintah daerah yang ingin mereplikasi inovasi ini agar perbaikan kinerja dalam memberikan layanan juga bisa dilakukan di daerah lain. 


\section{LANDASAN KONSEP}

\section{Konsep Inovasi}

Definisi inovasi menurut Kamus Besar Bahasa Indonesia adalah pemasukan atau pengenalan hal-hal yang baru; pembaharuan; atau penemuan baru yang berbeda dari yang sudah ada atau yang sudah dikenal sebelumnya.

Sedangkan menurut (Rogers, 1983), sebuah inovasi adalah suatu gagasan, praktik, atau proyek yang dianggap baru oleh individu atau unit adopsi lainnya. Kebaruan dari aspek inovasi tersebut dapat dinyatakan dalam bentuk pengetahuan, persuasi, atau keputusan untuk mengadopsinya.

Menurut Sengupta (2014), ada empat jenis inovasi yaitu inovasi berbasis teknologi, inovasi endogen dan eksogen, inovasi dalam mekanisme seleksi di pertumbuhan industri, dan inovasi melalui konsorsium teknologi. Terkait dengan inovasi berbasis teknologi, Tornatzky dan Fleischer dalam Carayannis, Samara \& Bakouros (2015) menjelaskan bahwa inovasi teknologi adalah perkembangan baru yang situasional untuk memperluas kontrol pada lingkungan. Jadi teknologi merupakan alat (tools) yang memungkinkan seseorang melakukan sesuatu yang baru.

Agar suatu inovasi dapat diadopsi dengan baik maka perlu adanya proses komunikasi atau dikenal dengan istilah difusi inovasi. Rogers (1983) mendefinisikan difusi sebagai suatu proses ketika inovasi dikomunikasikan melalui saluran tertentu dalam jangka waktu tertentu terhadap anggota suatu sistem sosial.

Jadi difusi dapat dikatakan sebagai suatu tipe komunikasi khusus yang pesannya adalah inovasi atau ide baru. Rogers (1983) lebih jauh menjelaskan bawa saluran komunikasi untuk menyebarkan inovasi adalah saluran media massa dan saluran interpersonal. Saluran media massa dapat melalui televisi, radio, atau koran. Sedangkan saluran interpersonal adalah komunikasi dua arah antara dua orang atau lebih.

\section{Inovasi di Sektor Publik}

Mulgan (2014) menjelaskan bahwa di sektor publik, inovasi bisa berarti hal yang berbeda. Bisa berarti cara baru untuk mengelola organisasi (seperti Public Private Partnerships), cara baru untuk memberikan reward, atau cara baru untuk berkomunikasi. Intinya, inovasi di sektor publik mencakup pembuatan, pengembangan, dan implementasi ide-ide praktis dalam rangka meraih manfaat publik. Suwarno (2008) menyatakan bahwa seiring dengan perubahan paradigma pelayanan, maka pemerintah sebagai penyedia jasa harus melakukan inovasi agar tujuan dan pencapaian dalam penyelenggaraan pelayanan publik dapat lebih baik lagi. Begitu pula hendaknya peran atau partisipasi masyarakat dalam perubahan ini juga ditingkatkan karena sejalan dengan misi pemberdayaan.

Pemerintah mengeluarkan kebijakan berupa Peraturan Pemerintah No. 38 Tahun 2017 Tentang Inovasi Daerah yang menyebutkan bahwa inovasi daerah adalah semua bentuk pembaruan dalam penyelenggaraan pemerintah daerah yang diarahkan untuk mempercepat terwujudnya kesejahteraan masyarakat melalui peningkatan pelayanan publik dan daya saing daerah, serta pemberdayaan dan partisipasi masyarakat. Ada tiga bentuk inovasi daerah, yaitu: inovasi tata kelola pemerintahan daerah, inovasi pelayanan publik, dan inovasi lainnya sesuai dengan urusan pemerintahan yang menjadi kewenangan daerah. Inovasi tata kelola pemerintahan daerah adalah inovasi dalam pelaksanaan manajemen pemerintahan daerah yang meliputi tata laksana internal dalam pelaksanaan fungsi manajemen dan pengelolaan unsur manajemen. Inovasi pelayanan publik merupakan inovasi dalam penyediaan pelayanan kepada masyarakat yang meliputi proses pemberian pelayanan barang/jasa publik dan inovasi jenis dan bentuk barang/jasa publik. Sedangkan inovasi daerah lainnya artinya segala bentuk inovasi dalam penyelenggaraan urusan pemerintahan yang menjadi kewenangan pemerintah daerah. 
Agar bisa tergolong sebagai inovasi daerah, berikut ini kriterianya:

- Mengandung unsur pembaruan (seluruh atau sebagian);

- Bermanfaat bagi daerah dan/atau masyarakat;

- Tidak mengakibatkan pembebanan dan/atau pembatasan pada masyarakat yang tidak sesuai dengan ketentuan peraturan perundang-undangan;

- Merupakan urusan pemerintahan yang menjadi kewenangan daerah, dan

- Dapat direplikasi.

Kemudian untuk mendorong pertumbuhan inovasi di sektor publik, Kementerian Pendayagunaan Aparatur Negara dan Reformasi Birokrasi (Kemenpan RB) menyelenggarakan Kompetisi Inovasi Pelayanan Publik (SINOVIK) di lingkungan kementerian/lembaga, pemerintah daerah (Pemda), Badan Usaha Milik Negara (BUMN) dan Badan Usaha Milik Daerah (BUMD).

Inovasi pelayanan publik yang dimaksud oleh Kemenpan RB adalah terobosan jenis pelayanan publik baik yang merupakan gagasan/ide kreatif orisinal dan/atau adaptasi/modifikasi yang memberikan manfaat bagi masyarakat, baik secara langsung maupun tidak langsung. Inovasi pelayanan publik dapat berupa inovasi dalam tata kelola pemerintahan, penggunaan Teknologi Informasi dan Komunikasi (TIK) dalam penyelenggaraan pelayanan publik, perbaikan kesejahteraan sosial dalam penyelesaian masalah-masalah sosial, dan pelayanan langsung kepada masyarakat. Sejalan dengan kebijakan inovasi daerah, kriteria inovasi pelayanan publik dalam SINOVIK adalah sebagai berikut:

- Memperkenalkan pendekatan baru, yaitu: memperkenalkan gagasan yang unik, pendekatan yang baru dalam penyelesaian masalah, atau kebijakan dan desain pelaksanaan yang unik, atau modifikasi dari inovasi pelayanan publik yang telah ada, dalam rangka penyelenggaraan pelayanan publik;
- Produktif atau terbukti hasil implementasinya;

- Berdampak yaitu bermanfaat terhadap peningkatan kondisi dan sebagai daya ungkit terhadap percepatan peningkatan kualitas pelayanan publik;

- Berkelanjutan yaitu memberikan jaminan bahwa inovasi tersebut terus dipertahankan, diimplementasikan, dan dikembangkan dengan dukungan program dan anggaran, tugas dan fungsi organisasi, serta hukum dan perundangundangan.

\section{METODE PENELITIAN}

Penelitian ini menggunakan metode kualitatif dengan pendekatan studi kasus. Creswell (2009) menjelaskan bahwa studi kasus adalah penelitian ketika peneliti menggali suatu kasus tertentu dalam suatu waktu dan kegiatan serta mengumpulkan informasi secara terinci dan mendalam dengan menggunakan berbagai prosedur pengumpulan data selama periode tertentu. Penelitian berfokus secara intensif pada suatu objek tertentu dan dilakukan analisis secara tajam terhadap berbagai faktor terkait dengan kasus yang diteliti sehingga dapat memperoleh simpulan yang akurat (Tasrin \& Pratiwi, 2016).

Berbagai sumber informasi penelitian diperoleh melalui: 1) Wawancara mendalam dengan informan kunci atau pihak-pihak yang paling mengetahui mengenai program SIP Bdg Juara ini. Informan kunci dalam penelitian ini adalah beberapa narasumber dari Sekretariat Daerah pada Asisten Pemerintahan di Bagian Pemerintahan Umum Kota Bandung, Camat Bandung Wetan; dan Lurah Cihapit. 2) Observasi, penulis selain menjadi pengamat ketika proses wawancara di kewilayahan, juga berpartisipasi sebagai masyarakat yang menggunakan inovasi tersebut. 3) Dokumentasi dan laporan yang diperoleh dari dokumen atau laporan Pemerintah Kota Bandung, hasil-hasil kajian/penelitian sebelumnya, dan peraturan perundang-undangan yang terkait. 


\section{HASIL PENELITIAN DAN PEMBAHASAN}

Sejak kepemimpinan Ridwan Kamil sebagai walikota, Pemerintah Kota Bandung melahirkan banyak inovasi yang berkaitan dengan teknologi. Hal ini memang perlu dilakukan karena inovasi yang berbasis teknologi bukan hanya sebatas melahirkan produk baru namun juga merupakan kunci insentif untuk mendorong perubahan dalam masyarakat serta meningkatkan daya saing dan pembangunan nasional (Carayannis, Samara \& Bakouros, 2015). Pemerintah Kota Bandung yang merupakan bagian dari sistem kota karena menjalankan roda pemerintahan, tentunya juga tak luput jadi sasaran pemanfaatan teknologi agar dapat menjadi smart government. Oleh karena itu, Pemerintah Kota Bandung cenderung berorientasi pada TIK untuk mendukung program kerjanya. Salah satu inovasi pemerintah Kota Bandung yang berorientasi pada TIK adalah SIP Bdg Juara.

\section{Tahapan Pengembangan Aplikasi SIP Bdg Juara}

Pengembangan inovasi SIP Bdg Juara ini berawal dari keinginan Walikota Ridwan
Kamil pada awal kepemimpinannya di akhir tahun 2013 agar Pemerintah Kota Bandung memiliki sistem penilaian khusus terkait dengan kinerja camat dan lurah (Rapor Camat dan Lurah). Maka pada tahun 2014, Bagian Pemerintahan Umum Sekretariat Daerah membangun SIP Bdg Juara.

Pada awal sistem ini dikembangkan, kinerja kecamatan dan kelurahan hanya dinilai oleh warga (sesuai dengan tujuan awal dibangunnya sistem ini). Namun berdasarkan hasil evaluasi pada pertengahan tahun 2014, hasil penilaian dari warga tidak dapat menggambarkan sesuatu. Hal ini karena pada sistem ini belum bisa menyaring apakah warga yang memberi penilaian tersebut merupakan warga kecamatan dan kelurahan. Selain itu, karena kurangnya sosialisasi, maka data penilaian yang masuk dari warga masih sangat minim. Oleh karena itu, untuk mendapatkan gambaran mengenai kinerja dari kewilayahan maka Bagian Pemerintahan Umum meminta laporan kegiatan dari kecamatan dan kelurahan secara manual. Namun setelah dievaluasi kembali pada akhir tahun 2014, diperoleh kenyataan bahwa ternyata masih banyak kecamatan dan kelurahan yang tidak mengisi laporan kegiatan secara manual.

Mekanisme penilaian dilakukan menggunakan sistem infomasi

elektronik melalui SIP Bdg Juara di alamat http://sip.bandung.go.id.

Camat dan lurah mengunggah profil wilayah, data, laporan kegiatan yang berkaitan dengan instrumen penilaian melalui SIP Bdg Juara.

Data atau laporan kegiatan yang masuk ke dalam SIP Bdg Juara diverifikasi oleh Tim Penilai dan ditinjau kelapangan.

Hasil rekapitulasi penilaian dituangkan dalam berita acara penilaian yang ditandatangani oleh Tim Penilai evaluasi kinerja camat dan lurah.

Hasil penilaian dituangkan dalam lembar Perjanjian Kinerja Camat dan lembar Perjanjian Kinerja Lurah yang akan disampaikan pada setiap akhir tahun anggaran. 
Kemudian, pada tahun 2015 sistem pelaporan online mulai dijalankan. Tampilan dari situs SIP Bdg Juara dirancang untuk mobile friendly. Selanjutnya pada tahun 2016, dikembangkan sistem penilaian dari warga melalui situs SIP Bdg Juara dengan proses identifikasi warga melalui akun media sosial (Facebook atau Twitter).

Mekanisme penilaian kinerja camat dan lurah di lingkungan Pemerintah Kota Bandung secara umum diatur oleh Peraturan Walikota No. 1354 Tahun 2014, disajikan pada Gambar 1, yang merupakan gambaran singkat mengenai tahapannya. Instrumen penilaian untuk mengukur kinerja camat dan lurah ditetapkan secara bersama dan selaras dengan Perjanjian Kinerja mereka setiap tahunnya. Terdapat dua kategori penilaian yaitu penilaian internal dan penilaian eksternal.

Untuk penilaian internal, kinerja camat dan lurah diukur oleh Tim Penilai berdasarkan laporan atau data yang diunggah oleh pihak kecamatan dan kelurahan pada aplikasi SIP Bdg Juara. Setiap kecamatan dan kelurahan mengakses aplikasi SIP Bdg Juara secara online melalui akun masing-masing untuk mengunggah berbagai laporan yang dibutuhkan. Terdapat empat aspek yang dinilai dalam penilaian internal yaitu: 1) Kualitas pelayanan publik; 2) Kinerja Penyelenggara Tugas Umum Pemerintahan; 3) Ketertiban, kebersihan, keindahan, dan lingkungan hidup; 4) Inovasi, kreativitas, dan peningkatan indeks kebahagiaan.

Adapun instrumen penilaian dari masing-masing aspek tersebut dibagi menjadi dua jenis yaitu laporan bulanan dan laporan tahunan. Selain instrumen penilaian di atas, aplikasi SIP Bdg Juara juga digunakan untuk penilaian lainnya terkait dengan kecamatan dan kelurahan. Misalnya penilaian untuk adipura, aplikasi SIP Bdg Juara menjadi media untuk mengunggah, memverifikasi, dan menilai data-data yang terkait penilaian adipura. Aplikasi ini memang dirancang dinamis, sehingga Bagian Pemerintahan Umum sebagai pengelola bisa menambahkan instrumen penilaian dan menu aplikasi sesuai perkembangan kebutuhan.
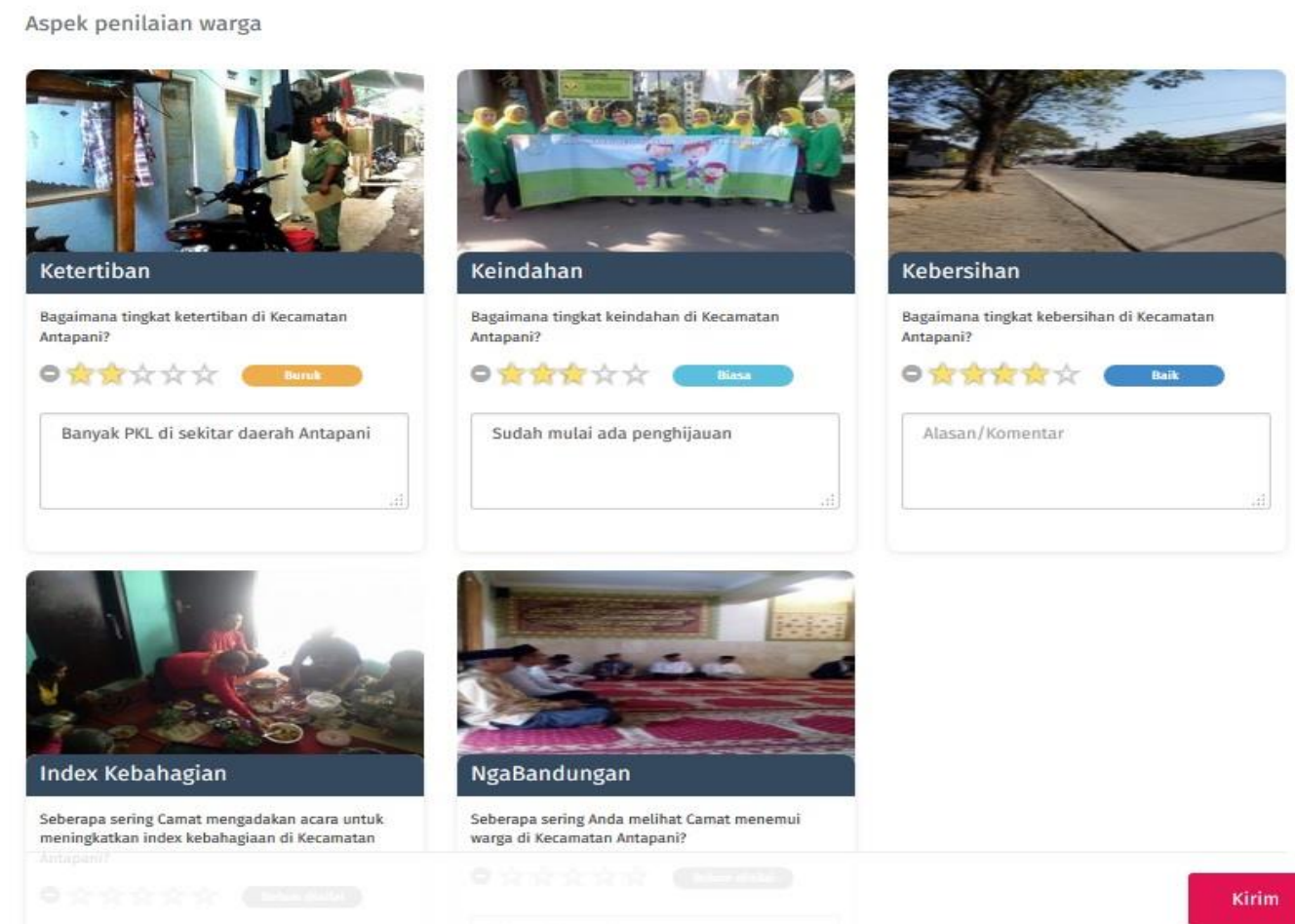

Antapani?
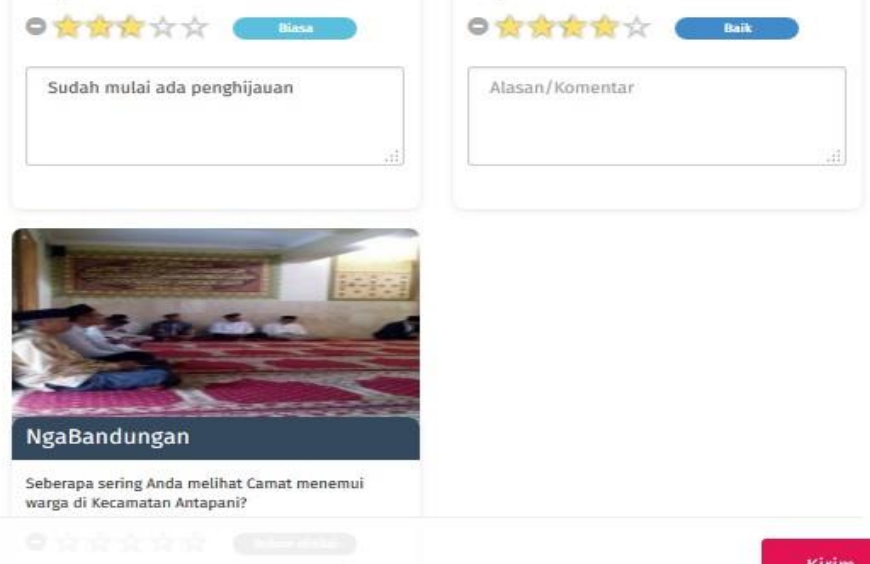

Sumber: Screenshoot oleh penulis dari situs SIP Bdg Juara: http://sip.bandung.go.id/ (2016)

Gambar 2. Tampilan Instrumen Aspek Penilaian Warga untuk Kecamatan dan Kelurahan di Website SIP Bdg Juara. 
Sedangkan untuk penilaian eksternal yang diberikan oleh warga dilakukan melalui laman situs SIP Bdg Juara di laman http://sip.bandung.go.id. Warga diminta untuk menilai kinerja kecamatan atau kelurahan tempat mereka berdomisili dari beberapa aspek, yaitu: ketertiban, keindahan, kebersihan, index kebahagiaan, ngabandungan (berinteraksi atau perhatian dengan warga), dan pelayanan publik. Adapun bentuk form penilaian yang disediakan untuk warga dalam menilai kinerja layanan kecamatan dan kelurahan adalah seperti yang disajikan di Gambar 2. Pada form di atas, warga diminta untuk memilih jumlah bintang pada 5 (lima) aspek penilaian (ketertiban, keindahan, kebersihan, index kebahagiaan, dan ngaBandungan). Jumlah bintang tersebut mewakili nilai untuk setiap aspek. Satu bintang berarti aspek tersebut bernilai sangat buruk, dua bintang artinya buruk, tiga bintang artinya biasa, empat bintang maksudnya baik, sedangkan 5 (lima) bintang berarti sangat baik. Selain itu, warga juga bisa memberikan alasan penilaian atau komentar mengenai aspek tersebut di kotak yang telah disediakan. Sedangkan untuk menilai aspek pelayanan publik di kecamatan dan kelurahan, disediakan form seperti
Gambar 3. Jadi disamping rating bintang untuk menilai setiap pelayanan publik yang diberikan oleh kecamatan dan kelurahan, warga juga diminta untuk mengisi infomasi tentang berapa lama waktu yang dibutuhkan untuk memproses layanan yang mereka butuhkan. Lalu setelah warga mengirim penilaiannya, warga kemudian diminta untuk koneksi dengan akun media sosial (Facebook atau Twitter) agar penilaiannya dapat dihitung. Hal ini dilakukan untuk mengantisipasi warga yang tidak sesuai domisili dengan kecamatan dan kelurahan yang dinilainya, juga untuk menghindari penilaian dari pihak yang tidak bertanggung jawab. Sehingga diharapkan nilai yang masuk merupakan data yang valid. Jika warga sudah login ke salah satu akun media sosial, maka warga akan diminta untuk melengkapi data diri pada form yang telah disediakan. Data nama dan kelurahan domisili otomatis akan tampil sesuai dengan data pada media sosial dan wilayah yang dipilih sebelumnya. Sedangkan data yang harus dilengkapi adalah Nomor Induk Kependudukan (NIK) dan nomor telepon seluler. Setelah melengkapi data diri, maka penilaian dari warga akan masuk perhitungan dan diverifikasi oleh para verifikator di Bagian Pemerintahan Umum.

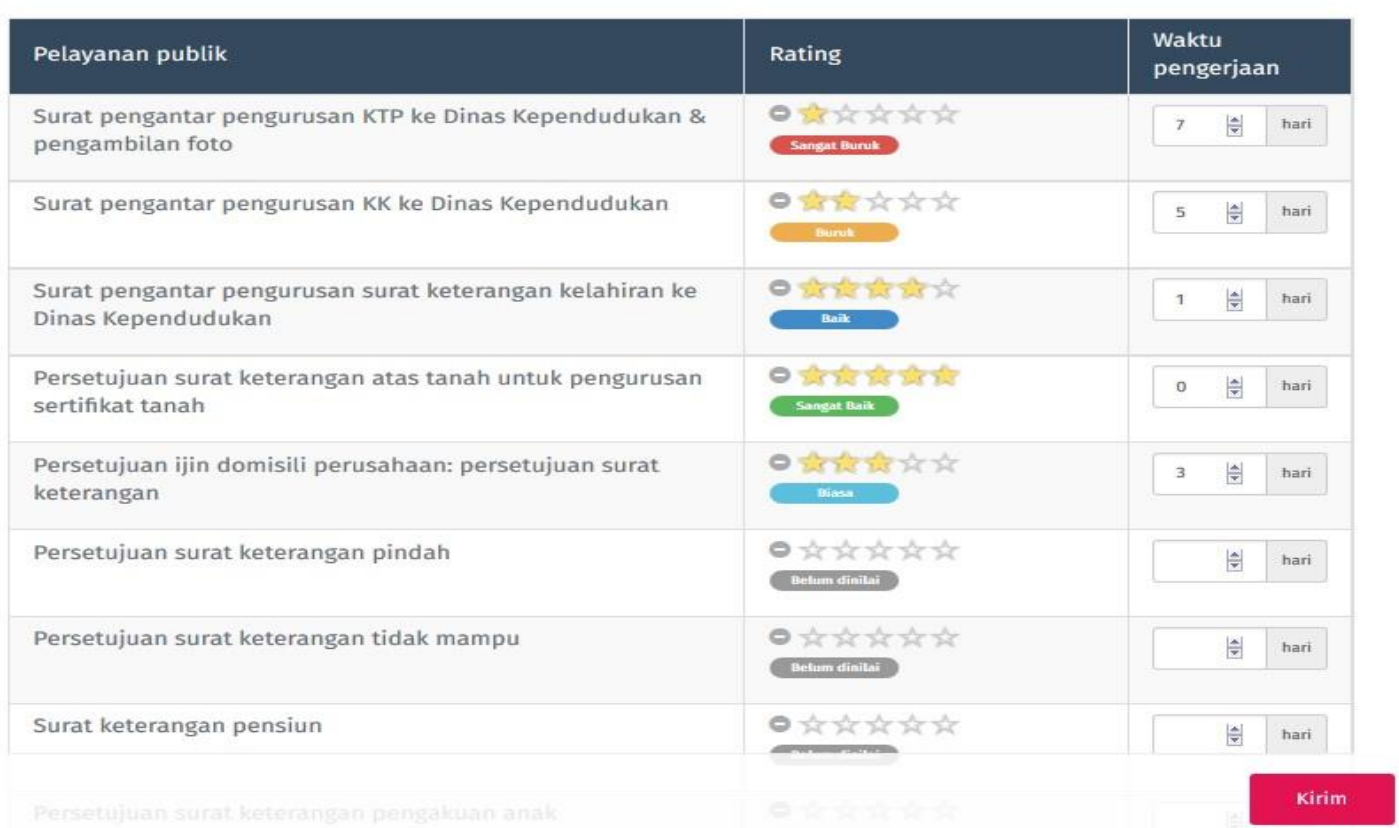

Sumber: Screenshoot oleh penulis dari situs SIP Bdg Juara: http://sip.bandung.go.id/ (2016)

Gambar 3. Tampilan Instrumen Pelayanan Publik untuk Kecamatan dan Kelurahan di Webiste SIP Bdg Juara. 
Jika dilihat dari proses inisiasi sampai tahap pengembangannya, seperti yang dijelaskan sebelumnya, program SIP Bdg Juara sudah dapat dikategorikan sebagai sebuah inovasi dari Kota Bandung. Hal ini disebabkan aplikasi ini merupakan pendekatan baru (dengan memanfaatkan TIK) yang digunakan Pemerintah Kota Bandung dalam menyelesaikan permasalahan tata kelola pemerintahan ketika proses pelaporan dan pengawasan yang awalnya secara manual menjadi digital. Selain menjadi cara baru dalam mengelola organisasi, inovasi juga merupakan cara baru untuk memberikan reward (Mulgan, 2014) atau dalam hal ini adalah reward kepada aparat kecamatan dan kelurahan. Serta sebagai bentuk upaya perbaikan layanan dengan melibatkan partisipasi masyarakat dalam menilai kinerja pemerintah. Sebagaimana disampaikan oleh Cohen dan Uphoff dalam Sagita (2016) bahwa salah satu bentuk partisipasi masyarakat adalah participation in evaluation yaitu partisipasi masyarakat melalui keikutsertaan mengawasi kegiatan dan menilai kinerja pembangunan beserta hasilhasilnya.

Kemudian untuk menjamin keberlanjutan dari inovasi ini, Pemerintah Kota Bandung telah menyusun kebijakan yang menjadi landasan dasarnya serta menyediakan anggaran pengembangan dan maintenance setiap tahunnya. Dasar hukum dari SIP Bdg Juara adalah Peraturan Walikota Bandung No. 1354 Tahun 2014 Tentang Penilaian Kinerja Camat dan Lurah Se-Kota Bandung. Selain itu, Pemerintah Kota Bandung juga menerbitkan kebijakan berupa Keputusan Walikota Bandung yang menjadi dasar hukum untuk menetapkan susunan keanggotan tim dan kesekretariatan serta tugas pokoknya.

\section{Progres Implementasi Inovasi SIP Bdg Juara}

Sejauh ini, implementasi inovasi SIP Bdg Juara berjalan dengan baik jika dilihat dari pelaksanaan penilaian yang dilakukan oleh pihak internal. Sejak dilaksanakan dari tahun 2014, Pemerintah Kota Bandung telah berhasil melaksanakan penilaian kinerja kecamatan dan kelurahan selama dua kali, yaitu di tahun 2014 dan 2015. Sedangkan pada tahun 2016 masih dalam proses pengumpulan data sesuai dengan instrumen penilaian ini. Pada tahun 2014, sepuluh camat dan lurah yang terbaik kinerjanya pada tahun 2014 mendapatkan reward untuk studi banding ke Korea Selatan. Sedangkan pada tahun 2015, reward yang diberikan oleh Pemerintah Kota Bandung berupa short course ke Singapura. Kecamatan yang berhasil mendapatkan reward pada tahun 2015 adalah: Panyileukan, Buahbatu, Cinambo, Cibiru, Arcamanik, Lengkong, Bandung Wetan, Sukajadi, Antapani, dan Rancasari. Sedangkan sepuluh kelurahan terbaik pada tahun 2015 adalah: Neglasari, Sukagalih, Rancanumpang, Maleber, Palasari, Cipadung, Nyengseret, Pasirwangi, Cimincrang, dan Mekarjaya.

Kemudian jika dilihat dari implementasi penilaian dari pihak eksternal atau warga, ternyata tidak berjalan sukses seperti penilaian internal.

Jumlah penilaian dari warga masih sangat sedikit jika dibandingkan dengan jumlah penduduk Kota Bandung. Berdasarkan data per tanggal 4 Agustus 2016, jumlah warga yang berpartisipasi menilai kinerja kecamatan dan kelurahan masih sangat sedikit yaitu 12.329 partisipan untuk kecamatan dan 17.392 partisipan untuk kelurahan. Bahkan ada kelurahan yang tidak memperoleh penilaian sama sekali dari warganya. Padahal jumlah penduduk Kota Bandung untuk umur di atas 19 tahun pada tahun 2015 mencapai 1.662.060 jiwa (BPS Kota Bandung, 2015). Kecamatan Cibiru menjadi yang paling banyak dinilai oleh warganya, yaitu berjumlah 1.813 warga, kemudian diikuti oleh Kecamatan Ujungberung sebanyak 1.211 warga, dan Babakan Ciparay pada peringkat ketiga dengan 875 warga yang berpartisipasi. Untuk kelurahan, jumlah partisipan yang paling banyak menilai kinerja layanannya adalah Kelurahan Balonggede dengan 1.668 partisipan, diikuti oleh Kelurahan 
Sukabunglah dengan 804 partisipan, dan kemudian Kelurahan Pasirendah sebanyak 618 partisipan.

Selain itu, Bagian Pemerintahan Umum sedang mengupayakan cara agar dapat memastikan bahwa data yang masuk melalui aplikasi ini memang merupakan data yang valid dari warga. Data warga baru bisa dicek melalui dua pilihan akun media sosial yaitu: Facebook dan Twitter. Sedangkan untuk NIK yang dimasukkan belum bisa digunakan untuk mengecek data warga. Jadi data penilaian warga yang masuk sejauh ini belum bisa menggambarkan data sesungguhnya yang terjadi di lapangan atau belum bisa mewakili suara dari seluruh warga. Oleh karena itu, hasil penilaian yang masuk dari warga belum dijadikan indikator untuk mengukur kinerja camat dan lurah. Hasil penilaian hanya digunakan untuk informasi tambahan atau jadi data pembanding bagi tim penilai.

Sejauh ini, manfaat dari pengembangan SIP Bdg Juara sudah terlihat. Dari sisi internal Pemerintah Kota Bandung banyak manfaat yang diperoleh sejak adanya inovasi SIP Bdg Juara, yaitu: mempermudah pembinaan dan pengawasan terhadap kinerja kecamatan dan kelurahan, mempermudah proses pelaporan, komunikasi dan rentang kendali menjadi lebih mudah, dan evaluasi kinerja jadi lebih terarah. Pemangku kepentingan merasa lebih terarah karena target-target kinerja jelas terlihat dari indikator-indikator penilaian yang ada pada program SIP Bdg Juara dan menjadi acuan untuk menentukan perbaikan yang harus dilakukan.

Laporan kegiatan dan dokumen pendukung yang pada awalnya harus diajukan secara manual sekarang dapat dengan mudah dikirimkan setiap saat melalui aplikasi ini sehingga pihak kewilayahan dapat lebih menghemat biaya cetak laporan dan juga tenaga. Selain itu, para pimpinan dapat memantau langsung data pencapaian kinerja pada SIP Bdg Juara, sehingga kewilayahan menjadi terpacu untuk berkinerja lebih baik. Kemudian untuk kebermanfaatan, jika dilihat dari sisi masyarakat sebagai pengguna layanan, maka dampak yang dirasakan langsung oleh masyarakat terhadap penerapan inovasi belum bisa diukur secara pasti. Namun karena SIP Bdg Juara mampu mengungkit performa kewilayahan dalam pencapaian kinerja maka semestinya secara tidak langsung akan memberi dampak positif kepada kualitas layanan yang diberikan kepada masyarakat.

Sedangkan hambatan yang dihadapi Pemerintah Kota Bandung dalam pengembangan dan pelaksanaan SIP Bdg Juara sejauh ini adalah sumber daya manusia terutama untuk verifikator data dan operator di kecamatan dan kelurahan masih kurang baik dari segi kuantitas maupun kualitas, kecepatan jaringan internet masih tergolong lambat, koordinasi dengan Disdukcapil terkait NIK warga masih terhambat, serta penyediaan sarana prasarana pendukung seperti smartphone, layar sentuh belum sesuai kebutuhan.

\section{Kelebihan dan Kekurangan Inovasi SIP Bdg Juara}

Berdasarkan hasil temuan di lapangan dan analisis tim peneliti, kelebihan dari inovasi berbasis teknologi informasi ini adalah sebagai berikut: Pertama, dukungan pimpinan terutama Walikota Bandung, Ridwan Kamil, yang menjadi motor penggerak untuk mengembangkan inovasi ini menjadi faktor kunci keberhasilan implementasi SIP Bdg Juara. Selain memberikan ide, beliau juga memantau langsung bagaimana pelaksanaannya. Komitmen dan dukungannya mampu mendorong pihak-pihak yang terkait dengan inovasi ini. Kedua, inovasi SIP Bdg Juara memiliki dasar hukum yang kuat yaitu berupa: Peraturan Walikota No. 1354 Tahun 2014 Tentang Penilaian Kinerja Camat dan Lurah Se-kota Bandung dan Keputusan Walikota Nomor 100/Kep.521-Ass I/2015 Tentang Tim Penilai dan Sekretariat Evaluasi Kinerja Camat dan Lurah di Lingkungan Pemerintah Kota Bandung Tahun Anggaran 2015, sehingga memberi kepastian hukum bagi pelaksana dalam mengembangkan dan menerapkan SIP Bdg Juara, serta memberi 
jaminan terhadap keberlanjutan inovasi ini. Selanjutnya ketiga adalah koordinasi yang baik antar stakeholder tidak hanya melalui aplikasi dan pertemuan rutin secara langsung, namun juga memanfaatkan media komunikasi WhatsApp.

Keempat adalah instrumen penilaian dalam mengukur kinerja camat dan lurah sudah cukup komprehensif dengan disertai data dukung berupa laporan dan foto. Instrumen penilaian merupakan hasil kesepakatan bersama antara pimpinan, Bagian Pemerintahan Umum, dan kewilayahan. Instrumen penilaian juga disusun berdasarkan perjanjian kinerja para camat dan lurah di Kota Bandung sehingga hasil penilaian dapat memberikan gambaran kinerja mereka. Kelima, aplikasi SIP Bdg Juara yang dibangun bersifat user friendly dan dinamis sehingga dapat dengan mudah disesuaikan seiring dengan perkembangan kebutuhan. Keleluasaan dalam mengelola konten dari aplikasi ini mengurangi ketergantungan terhadap pihak ketiga sehingga jadi lebih efektif.

Terakhir adalah reward yang menggiurkan yaitu berupa berupa piagam penghargaan dan kesempatan untuk keluar negeri. Adanya penghargaan terhadap pencapaian kinerja tentunya akan memotivasi pihak terkait untuk mendapatkannya, yang sejauh ini pemberian reward tersebut berjalan dengan lancar.

Sedangkan beberapa kekurangan dari inovasi SIP Bdg Juara yang nantinya diharapkan dapat menjadi catatan penting untuk pengembangan ke depannya yaitu:pertama dari aspek perencanaan, SIP Bdg Juara dikembangkan dan dilaksanakan tanpa adanya dokumen rencana induk (masterplan).

Sehingga tahap-tahap pengembangan (milestones) SIP Bdg Juara tidak tertuang dengan jelas. Tanpa adanya rencana induk maka tidak tergambarkan dengan jelas mengenai latar belakang, tujuan, tahap-tahap pengembangan, dan hal lainnya terkait pengembangan SIP Bdg Juara. Menurut Utomo, (2017), masterplan inovasi dapat menjadi panduan praktis bagi aparat di manapun berada untuk merencanakan, mengelola, dan menjalankan inovasi mereka. Sehingga proses pengembangan kedepannya akan berjalan gamang karena tidak adanya acuan yang ditetapkan dari hasil perencanaan yang matang.

Kedua, sosialisasi ke warga masih kurang optimal. Belum ada strategi dari Pemerintah Kota Bandung untuk mendifusikan inovasi ini. Padahal tanpa adanya difusi, maka inovasi tidak akan menghasilkan kemanfaatan yang besar karena tidak dapat diketahui secara luas oleh pihakpihak diluar pelakunya (Utomo, 2017). Saluran komunikasi untuk mendifusikan inovasi baik berupa saluran media massa maupun saluran perseorangan (Rogers, 1983) belum diberdayakan secara maksimal. Setiap kecamatan dan kelurahan sebenarnya telah memiliki akun media sosial, namun tidak dimanfaatkan untuk sosialisasi inovasi ini kepada masyarakat.

Salah satu faktor yang menyebabkan hal ini adalah karena penilaian dari masyarakat belum dijadikan salah satu indikator dalam mengukur kinerja camat dan lurah, sehingga pihak kewilayahan kurang termotivasi untuk melakukan sosialisasi kepada warganya. Serta minimnya informasi baik di kantor kewilayahan maupun pada situs SIP Bdg Juara menyebabkan masyarakat tidak paham urgensi untuk berpatisipasi dalam memberikan penilaian.

Pada situs SIP Bdg Juara tidak disediakan petunjuk penggunaan. Selain itu, kelemahan lainnya adalah warga dibatasi login hanya dari dua media sosial yaitu: Facebook dan Twitter untuk melakukan penilaian. Padahal tidak semua warga mempunyai akun media sosial tersebut.

Hal-hal tersebut tentunya berdampak kepada rendahnya tingkat partisipasi masyarakat untuk memberi penilaian terhadap kinerja camat dan lurah di wilayahnya. Padahal partisipasi masyarakat memiliki peran yang penting dalam pelaksanaan pembangunan karena masyarakat merupakan sumber informasi mengenai gambaran kondisi dan kebutuhan daerah setempat (Conyers dalam Sagita, 2016). 


\section{Key Factors Pengembangan atau Prasyarat Operasional SIP Bdg Juara}

Salah satu syarat suatu inovasi dikatakan berhasil adalah dapat direplikasi. Dengan mereplikasi inovasi maka akan memperbanyak praktik inovasi secara cepat dengan mutu dan manfaat yang relatif sama dengan sumber aslinya, namun tentunya disesuaikan dengan kondisi dan kebutuhan pemakainya (Utomo, 2017).

Untuk mempermudah daerah lain mereplikasi inovasi SIP Bdg Juara, maka berikut ini hasil identifikasi mengenai prasyarat operasional yang dibutuhkan dalam mengembangkan inovasi ini:

1. Dukungan pemimpin, salah satu kunci keberhasilan inovasi ini adalah dukungan dari pimpinan jadi perlu adanya political will dari pemimpin daerah agar mau mengembangkan dan menerapkan sistem penilaian ini. Seorang pemimpin adalah orang yang mampu membimbing dan mengarahkan bawahannya ke arah tujuan yang benar serta memengaruhi perilaku mereka untuk menjadi inovatif (Jain dan Saakshi dalam Bouhali, Mekdad, Lebsir, et al. (2015). Oleh karena itu, perlu dukungan penuh dari pemimpin daerah atau instansi untuk mereplikasi dan mengembangkan program SIP Bdg Juara karena kehadiran sebuah inovasi tentunya akan disertai dengan perubahan dibeberapa aspek.

2. Dasar hukum sebagai landasan dasarnya dan menjamin keberlanjutan dari inovasi.

3. Komitmen stakeholder, yaitu penyamaan visi misi dan adanya kesepakatan bersama dalam menjalankan program ini juga menjadi faktor penentu keberhasilannya. Setiap pihak yang terlibat harus jelas tugas dan tanggung jawabnya dan menyadari bahwa semua unsur yang terlibat merupakan penentu keberhasilan inovasi ini. Dengan memperkuat komitmen dan kepercayaan antar stakholder maka akan menciptakan definisi yang jelas mengenai visi dan strategi serta dapat menghindari ketidakpastian dalam berbagai hal
(Borins, Pattakos \& Dundon, Bryson, Bender dalam Tasrin \& Pratiwi (2017).

4. Aplikasi Sistem Informasi Penilaian yang dinamis dan user friendly. Peran TIK dalam inovasi SIP Bdg Juara ini memang sangat penting karena baik data laporan kegiatan kewilayahan maupun data penilaian dari warga diunggah pada aplikasi ini. Jadi dapat dikatakan bahwa aplikasi SIP Bdg Juara merupakan inti dari inovasi ini. Dalam inovasi yang melibatkan berbagai pihak atau collaborative innovation memang diperlukan dukungan utama dari TIK karena dapat memfasilitasi koordinasi dan knowledge sharing dengan jangkauan yang luas namun minim biaya (Bommert, 2010).

5. Anggaran dibutuhkan dalam mengembangkan aplikasi sistem informasi penilaian dan juga untuk menunjang pelaksanaan kegiatan seperti proses penilaian, penyediaan sarana prasarana, dan reward. Berdasarkan pengalaman Pemerintah Kota Bandung, anggaran yang dibutuhkan tidak terlalu besar. Khusus untuk aplikasi SIP Bdg Juara jika ada daerah lain yang ingin mereplikasi, maka Pemerintah Kota Bandung telah bersedia menghibahkan aplikasi yang telah mereka kembangkan. Hal ini tentunya akan menjadi lebih efektif dan efisien bagi pemerintah daerah lain untuk mereplikasi inovasi ini.

6. Instrumen penilaian kinerja hendaknya disusun dan disepakati bersama. Serta instrumen penilaian kinerja ini harus jelas dan mampu mengukur kinerja kewilayahan. Perjanjian kinerja bisa menjadi acuan dalam menyusun instrumen penilaian.

7. Mekanime yang jelas dan perlu disusunnya Standar Operasional Prosedur dalam pelaksanaannya. Sehingga dapat menjadi acuan bagi pelaksanaanya, meminimalisir terjadinya kesalahan ketika diimplementasikan, menghindari tumpang tindih pelaksanaan tugas serta perlindungan hukum bagi pelaksananya (Permenpan No. 35 Tahun 2012). 
8. Sumber daya manusia setidaknya diperlukan tim penilai, tim sekretariat (termasuk di dalamnya verifikator), dan juga operator aplikasi di kecamatan dan kelurahan.

9. Sarana dan prasarana inti seperti perangkat komputer dan jaringan internet yang stabil. Perangkat pendukung seperti smartphone dan kamera juga diperlukan untuk mendokumentasikan kegiatan yang akan dilaporkan.

\section{PENUTUP}

\section{Simpulan}

Sejak diimplementasikan dari tahun 2014, proses pelaksanaan inovasi SIP Bdg Juara cukup berjalan lancar. Walaupun masih ada beberapa kendala yang dihadapi oleh Pemerintah Kota Bandung, namun upaya untuk mengembangkan program ini terus dilakukan setiap tahunnya. Sejauh ini, program SIP Bdg Juara sudah dapat dikategorikan sebagai inovasi daerah. Melalui SIP Bdg Juara, Pemerintah Kota Bandung mengembangkan pendekatan yang baru dalam menyelesaikan masalah kinerja di kewilayahan. Program ini juga sudah terbukti hasil implementasinya karena proses pelaporan dan pengawasan menjadi lebih mudah. Walaupun penilaian dari warga belum dijaring secara optimal, namun penilaian internal melalui SIP Bdg Juara ini sudah mampu mendorong camat, lurah, dan jajarannya untuk meningkatkan kinerja pelayanan publik. Indikator penilaian juga sudah cukup komprehensif untuk menggambarkan kinerja kewilayahan dalam memberikan pelayanan publik. Ketersediaan dasar hukum dan anggaran juga memberikan jaminan keberlanjutan inovasi ini. Selain itu, inovasi ini juga cukup mudah untuk direplikasi karena Pemerintah Kota Bandung sangat mendukung inovasi ini untuk diterapkan di daerah lain.

\section{Saran}

Adapun rekomendasi atau saran dengan mempertimbangkan berbagai kekurangan yang ada pada Sistem Informasi Penilaian Bdg Juara adalah sebagai berikut. Dari aspek perencanaan, perlu disusun masterplan (rencana induk) pengembangan SIP Bdg Juara. Rencana induk hendaknya disusun berdasarkan hasil studi dan mampu menggambarkan tahap-tahap pengembangan untuk beberapa tahun kedepan. Sehingga inovasi ini memiliki acuan yang jelas dalam pengembangannya. Adapun informasi dasar yang perlu ada di rencana induk sebuah inovasi adalah pengertian dan ciri-ciri inovasi tersebut agar tidak terjadi mispersepsi, alasan mengapa perlu ada inovasi tersebut atau latar belakang masalahnya, faktor pendorong dan penghambat inovasi, gambaran rencana inovasi tersebut dalam jangka tertentu (Utomo, 2017).

Terkait sosialisasi, Pemerintah Kota Bandung dapat menggunakan saluran media massa dan saluran perseorangan (interpersonal channel) agar dapat mendifusikan inovasi ini kepada masyarakat (Rogers, 1983). Media massa digunakan untuk meraih sasaran masyarakat yang lebih luas. Sedangkan saluran perseorangan atau peer to peer untuk meraih sasaran dengan lingkup lebih kecil. Saluran media massa yang dapat menjadi alternatif pilihan untuk sosialisasi adalah stasiun TV lokal, radio, dan media cetak lokal. Lalu optimalkan penggunaan akun media sosial (Facebook, Twitter, Instagram, dan YouTube) milik Pemerintah Kota Bandung terutama akun media sosial milik Bagian Pemerintahan Umum, kecamatan, dan kelurahan. Selain itu, karena diantara semua akun resmi atas nama Pemerintah Kota Bandung yang paling populer atau menarik minat masyarakat adalah milik Walikota Ridwan Kamil, maka dapat menjadi saluran prioritas untuk sosialisasi SIP Bdg Juara. Selanjutnya, media sosialisasi melalui saluran yang lebih pribadi dapat dilakukan dengan cara kerjasama dengan komunitas. Berhubung Bandung memiliki banyak komunitas yaitu lebih dari 3.000 komunitas, maka pemerintah bisa memanfaatkan komunitas untuk menjadi perantara atau penyambung mulut pemerintah kepada warga Bandung. Selain itu, 
optimalkan peran kecamatan dan kelurahan beserta jajarannya. Level organisasi yang paling dekat dengan masyarakat adalah kecamatan dan kelurahan yang dibantu oleh RT dan RW.

Oleh karena itu, perlu mendorong mereka untuk bersedia melakukan sosialisasi SIP Bdg Juara kepada warganya. Sosialisasi dapat dilakukan melalui papan pengumuman di kantor kecamatan dan kelurahan, surat imbauan, sosialisasi pada saat pertemuan dengan warga, dan lain-lain.

Strategi lain agar masyarakat mau memberi penilaian adalah dengan cara mengarahkan masyarakat untuk mengisi SIP Bdg Juara ketika mereka datang ke kantor kecamatan dan kelurahan atau ketika ada pertemuan dengan warga. Bagi warga yang tidak melek teknologi, maka bisa dilakukan usaha jemput bola. Jadi pihak kecamatan dan kelurahan mendatangi warga dan menuntun mereka untuk mengisi SIP Bdg Juara melalui aplikasi layar sentuh yang dibuat sesederhana mungkin.

Selain itu, hendaknya penilaian dari warga dijadikan indikator dalam mengukur kinerja kecamatan dan kelurahan. Sehingga penilaian terhadap kinerja kecamatan dan kelurahan menjadi lebih komprehensif. Penilaian tidak hanya dilihat dari kacamata internal yang dilihat dari bukti laporan dan dokumentasi, namun juga dari sisi eksternal yaitu masyarakat yang merasakan langsung bagaimana kualitas pelayanan publik yang mereka terima.

Terakhir, pada situs SIP Bdg Juara perlu ditambah informasi mengenai apa itu SIP Bdg Juara. Sebaiknya sertakan keterangan mengenai latar belakang, tujuan, manfaat dari SIP Bdg Juara sehingga warga paham mengenai inovasi ini dan tertarik untuk berpartisipasi. Perlu juga dibuat petunjuk penggunaan situs SIP Bdg Juara melalui menu Frequently Asked Question $(F A Q)$ agar situs menjadi lebih user friendly.

Rekomendasi yang disampaikan di atas, diharapkan dapat membantu Pemerintah Kota Bandung dan daerah lain yang ingin mereplikasinya untuk mengembangkan inovasi ini menjadi lebih optimal.

\section{DAFTAR PUSTAKA}

Bandung.Co (2015) Sistem Informasi Penilaian Bandung Online. [Online]. 2015. Bandung.Co. Available from: https://bandung.co/2015/07/sisteminformasi-penilaian-bandung-online/ [Accessed: 10 October 2017].

Bommert, B. (2010) Collaborative Innovation in the Public Sector. International Public Management Review. [Online] 11 (1), 1533. Available from: http://journals.sfu.ca/ipmr/index.php/ipmr/ar ticle/view/73.

Bouhali, R., Mekdad, Y., Lebsir, H. \& Ferkha, L. (2015) Leader Roles for Innovation: Strategic Thinking and Planning. Procedia Social and Behavioral Sciences. [Online] 18172-78. Available from: doi:10.1016/j.sbspro.2015.04.867.

BPS Kota Bandung (2015) Jumlah Penduduk Menurut Kelompok Umur dan Jenis Kelamin di Kota Bandung Tahun 2015. [Online]. 2015. Available from: https://bandungkota.bps.go.id/linkTabelStati s/view/id/18 [Accessed: 20 June 2017].

Carayannis, E.G., Samara, E.T. \& Bakouros, Y.L. (2015) Innovation and Entrepreneurship. Innovation, Technology, and Knowledge Management. [Online]. Cham, Springer International Publishing. Available from: doi:10.1007/978-3-319-11242-8.

Creswell, J.W. (2009) Research Design: Qualitative, Quantitative, and Mixed Methods Approaches. Thousand Oaks, California, Sage Publication.

Masnurdiansyah (2016) Ombudsman RI: Keluhan Buruknya Layanan Pemda Paling Tinggi. [Online]. 2016. detikNews. Available from: https://news.detik.com/berita-jawa-barat/d3330136/ombudsman-ri-keluhan-buruknyalayanan-pemda-paling-tinggi [Accessed: 1 November 2017].

Mulgan, G. (2014) Innovation in the Public Sector How Can Public Organisations Better Create, Improve and Adapt? 2014. Nesta.

Pikiran Rakyat (2017) Yossi Irianto: Partisipasi Masyarakat Jadi Ciri Kota yang Maju. [Online]. 2017. Available from: http://www.pikiran-rakyat.com/bandungraya/2017/09/16/yossi-irianto-partisipasimasyarakat-jadi-ciri-kota-yang-maju409571 [Accessed: 3 November 2017].

Rogers, E.M. (1983) Diffusion of Innovations. 
New York, Free Press.

Sagita, N.I. (2016) PARTISIPASI WARGA MASYARAKAT DALAM PENILAIAN KINERJA KECAMATAN DI KOTA BANDUNG. CosmoGov. [Online] 2 (2), 308-329. Available from: doi:10.24198/cosmogov.v2i2.10009.

Sengupta, J. (2014) Theory of Innovation. [Online]. Cham, Springer International Publishing. Available from: doi:10.1007/978-3-319-02183-6.

Suwarno, Y. (2008) Inovasi di Sektor Publik. Jakarta, STIA-LAN Press.

Tasrin, K. \& Pratiwi (2017) Building Local Sustainable Innovation through MultiStakeholders Partnership Model (Case Study: Bandung City, Indonesia). In: 2017 EROPA General Assembly and Conference. 2017 Seoul, Eastern Regional Organization for Public Administration.
Tasrin, K. \& Pratiwi (2016) Model Inovasi 'Wisata Buku Sahabat Anak' Dalam Rangka Meningkatkan Minat Baca Masyarakat Kabupaten Ciamis. Baban Sobandi (ed.). Bandung, Pusat Kajian dan Pendidikan dan Pelatihan Aparatur I Lembaga Administrasi Negara.

Utomo, T.W.W. (2017) Inovasi Harga Mati: Sebuah Pengantar Inovasi Administrasi Negara. Jakarta, Rajagrafindo Persada.

Wiseman, J. (2014) Innovations in Public Service Delivery: Can 311 Call Centers Improve Service Delivery? Lessons from New York and Chicago. [Online]. Available from: https://publications.iadb.org/bitstream/handl e/11319/6765/ICS_DP_Can_311_Call_Cent ers_Improve_Service_Delivery

final.pdf?sequence $=1$ [Accessed: 11 October 2017]. 